\title{
KARAKTERISTIK FISIK MIKROKAPSUL FIKOSIANIN SPIRULINA PADA KONSENTRASI BAHAN PENYALUT YANG BERBEDA
}

\section{PHYSICAL CHARACTERISTICS OF SPIRULINA PHYCOCYANIN MICROCAPSULES USING DIFFERENT CONCENTRATION OF COATING MATERIALS}

\author{
Lukita Purnamayati $^{1)}$, Eko Nurcahya Dewi ${ }^{1)}$, Retno Ayu Kurniasih ${ }^{1)}$ \\ 1) Program Studi Teknologi Hasil Perikanan Fakultas Perikanan dan Ilmu Kelautan Universitas Diponegoro \\ Jl.Prof. H. Soedarto, SH Tembalang Telp/Fax. (024) 7474698 Semarang-50275 \\ Email : lukita_anandito@yahoo.com
}

\begin{abstract}
Phycocyanin is a bright blue pigment in Spirulina sp. Microencapsulation can protect phycocyanin from environmental influences such as temperature, light, and pH. The aim of this study was to investigate the physical characteristics of phycocyanin microcapsules using maltodextrin and carrageenan as coating materials. Microcapsules were prepared with five variations different concentration of carrageenan and maltodextrin treatments i.e. $10 \%: 0 \% ; 9,75 \%: 0.25 \% ; 9,5 \%: 0.5 \% ; 9,25 \%: 0.75 \%$, and $9 \%: 1.0 \%(\mathrm{w} / \mathrm{w})$. Results indicated that phycocyanin microcapsules with carrageenan $1.0 \%$ produced the most blue color, the lowest soluble solid about $3.19 \%$ and the longest release time compared to other samples
\end{abstract}

Keywords: Phycocyanin, Microencapsulation, Physical characteristic

\begin{abstract}
ABSTRAK
Fikosianin merupakan pigmen biru Spirulina sp. Mikroenkapsulasi dapat melindungi fikosianin dari pengaruh lingkungan seperti suhu, cahaya, dan $\mathrm{pH}$. Tujuan dari penelitian ini adalah untuk mengetahui karakteristik fisik mikrokapsul fikosianin menggunakan maltodekstrin dan karagenan sebagai bahan penyalut. Mikrokapsul fikosianin dibuat dengan lima variasi konsentrasi maltodekstrin dan karagenan yaitu 10\%: $0 \%$; 9,75\%:0,25\%; $9,5 \%: 0,5 \% ; 9,25 \%: 0,75 \%$; dan $9 \%: 1 \%$ (b/b). Hasil menyatakan bahwa mikrokapsul fikosianin dengan perbandingan bahan penyalut maltodekstrin dan karagenan $9 \%: 1 \%(\mathrm{~b} / \mathrm{b})$ menghasilkan warna yang paling biru, zat padat terlarut yang paling rendah yaitu 3,19\% dan waktu release yang paling lama dibanding formula yang lain yaitu lebih dari 3 menit.
\end{abstract}

Kata Kunci : Fikosianin, Mikroenkapsulasi, Sifat fisik

\section{PENDAHULUAN}

Fikosianin merupakan salah satu pigmen yang terdapat pada Spirulina sp. Fikosianin merupakan pigmen polar, yang keberadaannya dalam Spirulina sp. bersama dengan allofikosianin dan fikoeritrin. Fikosianin berpotensi sebagai pewarna biru alami, karena dapat menghasilkan warna biru yang cerah. Selain itu, juga dapat dikembangkan sebagai zat aditif sebagai nutrisi fungsional dan tidak beracun (Sedjati $d k k .$, 2012). Fikosianin memiliki kemampuan sebagai antioksidan, yang mampu menghambat peroksidasi lipid pada tikus (Bertolin et.al., 2011).

Penggunaan fikosianin dalam bahan pangan sebagai pewarna alami sangat terbatas. Hal ini dikarenakan fikosianin tidak stabil terhadap suhu dan $\mathrm{pH}$. Fikosianin stabil pada kisaran $\mathrm{pH}$ 5,5 - 6 dan akan menurun stabilitasnya apabila disimpan pada suhu di atas $47^{\circ} \mathrm{C}$ (Chaiklahan et.al., 2012). Selain itu, fikosianin juga tidak stabil terhadap cahaya dan kelembaban. Fikosianin stabil pada kondisi penyimpanan yang gelap dengan kelembaban yang rendah (Yan et.al., 2014). Salah satu cara untuk mengatasi permasalahan tersebut adalah dengan memproses fikosianin menjadi bubuk dengan teknologi mikroenkapsulasi.

Mikroenkapsulasi merupakan suatu proses yang mengubah bahan padat maupun cair menjadi bentuk kapsul dalam ukuran mikro $(0,2-5000 \mu \mathrm{m})$. Proses ini bertujuan untuk melindungi dan mempertahankan 
komponen aktif dari pengaruh lingkungan. Metode mikroenkapsulasi yang sering digunakan yaitu dengan spray drying karena biayanya lebih rendah dan peralatannya yang mudah dijumpai. Pembentukkan kapsul dalam ukuran mikro dibutuhkan material lain sebagai material pelapis atau yang sering disebut dengan bahan penyalut.

Bahan penyalut yang digunakan dalam mikroenkapsulasi harus bersifat emulsifier, dapat membentuk lapisan film, dan dapat membuat bahan aktif menjadi a free flowing powder, sehingga mudah ditambahkan dalam bahan pangan. Komposisi material pelapis yang digunakan akan menentukan karakteristik fisik mikrokapsul seperti zat padat terlarut dan waktu release.

Salah satu bahan penyalut yang sering digunakan adalah maltodekstrin. Maltodekstrin merupakan produk hidrolisa pati yang mempunyai DE kurang dari 20 . Maltodekstrin mempunyai sifat mudah larut dalam air, dapat membentuk body, mampu membentuk film, mempunyai daya ikat yang kuat dan tidak berasa (Srihari $d k k$., 2010). Akan tetapi, maltodekstrin lemah dalam pembentukkan emulsi. Oleh karena itu, dalam penelitian ini, maltodekstrin dikombinasikan dengan karagenan.

Karagenan merupakan senyawa hidrokoloid yang diperoleh dengan cara mengekstrak rumput laut merah seperti Euchema cottonii. Penambahan karagenan dalam produk mampu meningkatkan kestabilan emulsi. Rojas-Nery et.al., (2015) menyatakan bahwa penambahan karagenan mampu membentuk emulsi yang kental dan stabil selama proses koagulasi rennet. Karagenan terbagi menjadi $\kappa$-karagenan, Ikaragenan dan $\lambda$-karagenan. Dari ketiga jenis karagenan tersebut, $\kappa$-karagenan yang mempunyai sifat gel yang baik (Setijawati $d k k$, 2011). Kemampuan $\kappa$-karagenan dalam membentuk gel inilah yang berhubungan dengan kemampuannya sebagai bahan penyalut.

Penelitian mengenai mikroenkapsulasi kebanyakan menggunakan maltodekstrin sebagai bahan penyalut (Supriyadi dan Rujita, 2013; Wariyah, 2014; Utami et.al., 2015).
Penelitian ini menggunakan bahan penyalut maltodekstrin yang dikombinasikan dengan karagenan untuk meningkatkan kualitas mikrokapsul. Penambahan karagenan diharapkan mampu membentuk emulsi yang baik pada campuran maltodekstrin, karagenan dan ekstrak fikosianin sehingga mampu memerangkap dan melindungi fikosianin saat dilakukan pengeringan dengan spray dryer. Penelitian ini bertujuan untuk mengetahui pengaruh penggunaan maltodekstrin dan karagenan terhadap karakteristik fisik mikrokapsul fikosianin.

\section{METODE PENELITIAN}

\section{Bahan}

Bahan yang digunakan adalah fikosianin yang berasal dari Spirulina sp. bubuk yang diperoleh dari PT. Neoalga, Sukoharjo, Indonesia. Sebagai bahan penyalut digunakan Maltodekstrin DE 10 diperoleh dari CV. Multi Kimia Raya, Semarang, Indonesia. $\kappa$-Karagenan diperoleh dari PT. Selalu Lancar Maju Karya, Jakarta, Indonesia.

\section{Alat}

Alat yang digunakan stirrer, hot plate (Daihan Lab Tech.co.Ltd), centrifuge (Wina Instruments, Indonesia), spray dryer (LabPlant Spray Dryer SD-05), timbangan analitik, gelas ukur, gelas beaker, dan chromameter (CR-200 Minolta).

\section{Tahapan Penelitian}

Ektraksi fikosianin berdasarkan Chaiklahan et.al., (2011) dengan modifikasi pada pelarut dan waktu pengadukan. Ekstraksi dilakukan dengan rasio spirulina : aquades (1:100) (w/v) dengan kecepatan homogenisasi $300 \mathrm{rpm}$ pada suhu ruang selama 4 jam. Selanjutnya dilakukan proses pemisahan dengan menggunakan sentrifus pada 4800 g selama 15 menit. Filtrat yang merupakan ekstrak fikosianin dipisahkan dari endapan dengan dekantasi.

Ekstrak fikosianin dienkapsulasi dengan menggunakan maltodekstrin dan 
karagenan. Perbandingan konsentrasi maltodekstrin dan karagenan yang digunakan adalah 10\%:0\% (A); 9,75\%: 0,25\% (B); $9,5 \%: 0,5 \%$ (C); $9,25 \%: 0,75 \%$ (D); dan $9 \%: 1 \%$ (E) (b/b). Selanjutnya suspensi dikeringkan dengan menggunakan spray dryer dengan suhu inlet $80^{\circ} \mathrm{C}$ dan suhu outlet $56^{\circ} \mathrm{C}$. Mikrokapsul fikosianin yang dihasilkan diuji karakteristik fisik meliputi :

1. Warna dengan chromameter

Warna mikrokapsul fikosianin dianalisa dengan menggunakan chromameter CR-200 (Minolta). Analisis ini mengukur nilai L, a, b dimana semakin tinggi nilai L maka semakin mengarah ke warna putih. Semakin negatif nilai a maka semakin mengarah pada warna hijau. Semakin positif nilai a maka semakin mengarah ke warna merah. Sedangkan semakin besar nilai negatif $b$ maka semakin mengarah pada warna biru, dan semakin positif nilai $b$ maka semakin mengarah ke warna kuning.

2. Zat Padat Terlarut (AOAC, 2005)

Analisa zat padat terlarut menggunakan metode thermogravimetri dengan cara memasukkan 0,5 g sampel bubuk dan aquades $6 \mathrm{~mL}$ ke dalam labu takar $100 \mathrm{~mL}$. Selanjutnya digojog dan dipanaskan dalam penangas air mendidih sampai 5 menit. Setelah didinginkan, ditambah aquades sampai sampai batas labu takar kemudian disaring. Filtrat yang diperoleh diambil $5 \mathrm{~mL}$ dan dituangkan ke dalam cawan porselin yang telah diketahui beratnya (A) g. Selanjutnya filtrat diuapkan di atas penangas air mendidih sampai kering. Selanjutnya dikeringkan lagi dalam oven pada suhu $105^{\circ} \mathrm{C}$ sampai diperoleh berat konstan (B) g. Kadar zat padat terlarut dihitung sebagai berikut :

$\mathrm{ZPT}(\% \mathrm{db})=(\mathrm{B}-\mathrm{A}) /$ Berat kering sampel $\mathrm{x}$ $10 / 0,5 \times 100 \%$

\section{Waktu release}

Waktu release fikosianin dilakukan dengan memodifikasi metode BelscakCvitanovic et al. (2011), yaitu mikrokapsul fikosianin $1 \%(\mathrm{w} / \mathrm{v})$ dalam aquades diaduk secara berkelanjutan. Selanjutnya larutan diambil $1 \mathrm{Ml}$ setiap 30 detik untuk dilakukan analisis kadar fikosianin.

\section{Analisis Statistik}

Penelitian ini menggunakan Rancangan Acak Lengkap dengan satu faktor perlakuan, yaitu berbagai perbandingan konsentrasi maltodekstrin-karagenan, dimana setiap perlakuan dilakukan tiga kali ulangan. Data yang diperoleh dianalisis dengan sidik ragam atau Analysis of Varians (ANOVA). Jika terdapat perbedaan antar perlakuan maka diuji lanjut dengan Uji Tukey pada $\alpha=0,05$ untuk mengetahui perlakuan mana yang berbeda. Analisis dilakukan dengan SPSS 17.

\section{HASIL DAN PEMBAHASAN}

Hasil rendemen ekstrak fikosianin pada penelitian ini diperoleh adalah 93,36\%. Hasil yang berbeda diperoleh oleh Sivasankari et.al., (2014) yang mengekstrak fikosianin dari Spirulina dengan sodium buffer fosfat dengan inkubasi selama 48 jam menghasilkan fikosianin sebanyak 25\%. Supu $d k k$., (2013) juga melakukan ekstraksi fikosianin dari biomassa Spirulina menggunakan buffer fosfat dengan perbandingan biomassa dan buffer fosfat $0,04 \mathrm{~g} / \mathrm{ml}$. Ekstrak fikosianin yang diperole kemudian dikeringkan dengan freeze dryer. Dari 80 liter campuran biomassa dan buffer fosfat, dihasilkan 5,5 g fikosianin bubuk.

Fikosianin merupakan pigmen polar sehingga dapat larut pada pelarut polar pula, seperti air dan buffer daripada pelarut non polar. Hasil yang diperoleh pada penelitian ini lebih tinggi. Hal ini dipengaruhi oleh kondisi ekstraksi dimana pada penelitian ini dilakukan pengadukan untuk homogenisasi Spirulina bubuk dengan aquades. Pengadukan menyebabkan kontak antara Spirulina dan pelarut semakin besar sehingga fikosianin yang terekstrak juga semakin banyak. Selain itu, volume pelarut juga mempengaruhi rendemen ekstraksi. Hal ini sesuai dengan Yuniwati $d k k$. , (2012) yang mengekstrak zat warna pada daun suji dengan pelarut etanol, menyatakan bahwa ekstraksi dengan kecepatan pengadukan $300 \mathrm{rpm}$ dengan rasio daun suji $5 \mathrm{gr}$ dalam $200 \mathrm{ml}$ pelarut menghasilkan rendemen ekstrak paling besar. 


\section{Warna}

Hasil pengukuran warna mikrokapsul fikosianin dengan chromameter disajikan pada Tabel 1, dimana kelima formula mikrokapsul fikosianin mempunyai warna $\mathrm{L}$ $(+)$, yang menunjukkan bahwa tingkat kecerahan warna yang tinggi. Nilai a (-), menunjukkan bahwa warna mengarah ke hijau dan nilai b (-) menunjukkan bahwa warna mengarah ke biru.

Mikrokapsul fikosianin dengan perbandingan maltodekstrin dan karagenan 9\%:1\% (E) mempunyai warna paling biru dibanding formula yang lain. Warna biru menunjukkan banyaknya kandungan fikosianin. Fikosianin merupakan pigmen biru alami yang terdapat pada Spirulina sp. (Sedjati $d k k ., 2012$ ) yang mempunyai sifat sebagai antioksidan. Berdasarkan penangkapan radikal bebas dengan DPPH, fikosianin mampu menurunkan $83 \%$ radikal bebas oksigen (Seo et.al., 2013). Kemampuan antioksidan fikosianin juga diuji dengan penangkapan radikal bebas menggunakan asam nitrat, menghasilkan penghambatan sebesar 92,58\% (Kamble et.al., 2013). Namun, fikosianin tidak tahan terhadap suhu (Chaiklahan et.al., 2012; Yan et.al., 2014).

Perbedaan intensitas warna biru ini dipengaruhi oleh perbedaan rasio bahan penyalut. Hal ini dapat dilihat pada Formula A, B, C, dan D memiliki warna biru yang pudar, ditunjukkan pada tingginya nilai L dan rendahnya nilai $b$ dibanding Formula $\mathrm{E}$.
Berdasarkan Purnomo dkk., (2014) yang melakukan mikroenkapsulasi ekstrak daun jati dengan maltodekstrin dan karagenan, menghasilkan warna merah mikrokapsul yang lebih rendah dibandingkan dengan ekstrak daun jati tanpa penyalut. Hal ini menandakan bahwa penggunaan maltodekstrin dan karagenan sebagai bahan penyalut mampu mempertahankan dan melindungi bahan yang disalutnya selama proses pengeringan dengan spray dryer.

Maltodekstrin sebagai bahan penyalut memiliki sifat browning yang rendah (Srihari $d k k$. 2010), sehingga pada saat proses mikroenkapsulasi tidak mempengaruhi warna mikrokapsul yang dihasilkan. Sedangkan karagenan memiliki kemampuan untuk membentuk gel dimana mampu mengubah bahan cair menjadi bentuk padat. Karagenan mempunyai titik leleh pada suhu $41^{\circ} \mathrm{C}-43^{\circ} \mathrm{C}$ dan mulai membentuk gel pada titik jendal $30^{\circ} \mathrm{C}-33^{\circ} \mathrm{C}$ (Wenno dkk., 2012). Berdasarkan analisis gugus fungsi dengan FTIR, karagenan mengandung 3,6 anhydrogalactose dan galactose 4 sulphate yang diidentifikasi sebagai $\kappa$-karagenan, dimana $\kappa$-karagenan mempunyai sifat mampu membentuk gel yang kuat (Dewi et.al., 2012). Setijawati (2014) melakukan enkapsulasi Lactobacillus acidophilus menggunakan karagenan karena kemampuannya dalam membentuk gel. Kappa karagenan yang digunakan dalam penelitian ini, mampu memerangkap fikosianin dan melindungi fikosianin selama proses mikroenkapsulasi.

Tabel 1. Nilai Warna Mikrokapsul Fikosianin

\begin{tabular}{ccccc}
\hline No. & Sampel & $\mathrm{L}$ & $\mathrm{a}$ & $\mathrm{b}$ \\
\hline 1. & A & $80,72^{\mathrm{a}} \pm 1,32$ & $-6,72^{\mathrm{a}} \pm 0,20$ & $-9,79^{\mathrm{b}} \pm 0,29$ \\
2. & $\mathrm{~B}$ & $81,42^{\mathrm{a}} \pm 0,74$ & $-5,71^{\mathrm{c}} \pm 0,13$ & $-9,08^{\mathrm{a}} \pm 0,16$ \\
3. & $\mathrm{C}$ & $81,31^{\mathrm{a}} \pm 0,74$ & $-5,96^{\mathrm{b}} \pm 0,02$ & $-10,41^{\mathrm{c}} \pm 0,17$ \\
4. & D & $79,20^{\mathrm{b}} \pm 0,83$ & $-4,55^{\mathrm{d}} \pm 0,06$ & $-11,21^{\mathrm{d}} \pm 0,15$ \\
5. & E & $75,52^{\mathrm{c}} \pm 1,22$ & $-3,98^{\mathrm{e}} \pm 0,02$ & $-11,68^{\mathrm{e}} \pm 0,29$ \\
\hline
\end{tabular}

Keterangan: $\mathrm{A}=$ Mikrokapsul dengan perbandingan konsentrasi maltodekstrin dan karagenan 10\%:0\%; B = Mikrokapsul dengan perbandingan konsentrasi maltodekstrin dan karagenan 9,75\%:0,25\%; $\mathrm{C}=$ Mikrokapsul dengan perbandingan konsentrasi maltodekstrin dan karagenan 9,5\%:0,5\%; D = Mikrokapsul dengan perbandingan konsentrasi maltodekstrin dan karagenan 9,25\%:0,75\%; E = Mikrokapsul dengan perbandingan konsentrasi maltodekstrin dan karagenan 9\%:1\%. Data \pm standar deviasi. Superscript yang berbeda pada kolom yang sama menunjukkan berbeda nyata pada taraf $\alpha 0,05$ 


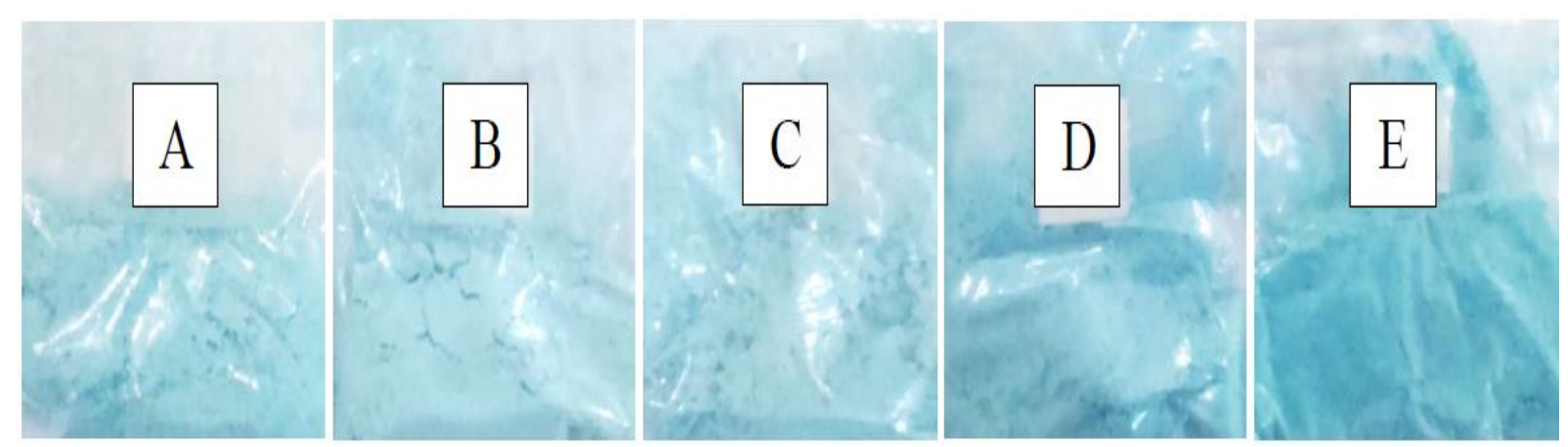

Gambar 1. Mikrokapsul Fikosianin Formula A, B, C, D, dan E

\section{Zat Padat Terlarut}

Analisa zat padat terlarut mikrokapsul fikosianin dimaksudkan untuk mengetahui kemampuan produk mikrokapsul fikosianin yang dihasilkan dapat larut dalam air. Hasil analisis zat padat terlarut dapat dilihat pada Tabel 2.

Tabel 2. Nilai zat padat terlarut mikrokapsul

\begin{tabular}{lcc}
\hline No. & Sampel & ZPT $(\%)$ \\
\hline 1. & A & $7,62^{\mathrm{a}} \pm 0,37$ \\
2. & B & $6,91^{\mathrm{ab}^{\mathrm{b}} \pm 1,49}$ \\
3. & $\mathrm{C}$ & $5,14^{\mathrm{bc}} \pm 0,07$ \\
4. & $\mathrm{D}$ & $4,90^{\mathrm{bc}} \pm 0,10$ \\
5. & E & $3,19^{\mathrm{c}} \pm 0,72$ \\
\hline
\end{tabular}

Keterangan: $\mathrm{A}=$ Mikrokapsul dengan perbandingan konsentrasi maltodekstrin dan karagenan 10\%:0\%; B = Mikrokapsul dengan perbandingan konsentrasi maltodekstrin dan karagenan 9,75\%:0,25\%; C = Mikrokapsul dengan perbandingan konsentrasi maltodekstrin dan karagenan 9,5\%:0,5\%; D = Mikrokapsul dengan perbandingan konsentrasi maltodekstrin dan karagenan 9,25\%:0,75\%; E = Mikrokapsul dengan perbandingan konsentrasi maltodekstrin dan karagenan 9\%:1\%. Data \pm standar deviasi Superscript yang berbeda pada kolom yang sama menunjukkan berbeda nyata pada taraf $\alpha 0,05$.

Hasil tersebut menunjukkan bahwa semakin rendah konsentrasi maltodekstrin dan semakin tinggi konsentrasi karagenan sebagai bahan penyalut menyebabkan penurunan zat padat terlarut. Semakin tinggi konsentrasi maltodekstrin dapat meningkatkan zat padat terlarut karena maltodekstrin memiliki sifat kelarutan dalam air yang baik. Kanpairo et.al., (2012) menyatakan bahwa penambahan maltodekstrin dapat meningkatkan zat padat terlarut pada tuna precooking concentrate.

Peningkatan konsentrasi karagenan menyebabkan penurunan zat padat terlarut. Hal ini disebabkan oleh sifat karagenan yang tidak larut dalam air dingin. Rendahnya zat padat terlarut pada Formula E disebabkan karagenan cenderung membentuk gel setelah dipanaskan dan didinginkan pada suhu kamar, sehingga pada saat pengambilan filtrat, karagenan telah membentuk gel. Pada dasarnya pengukuran zat padat terlarut dengan metode thermogravimetri adalah melarutkan sampel dalam air dan memanaskan sampai mendidih dan didinginkan, filtrat diambil dan dipanaskan dalam cawan kemudian dioven. Sifat karagenan adalah membentuk jendalan atau gel pada saat didiamkan atau sering disebut dengan sifat thermoreversible.

\section{Waktu Release}

Waktu release fikosianin dari mikrokapsul fikosianin dapat dilihat pada Gambar 2.

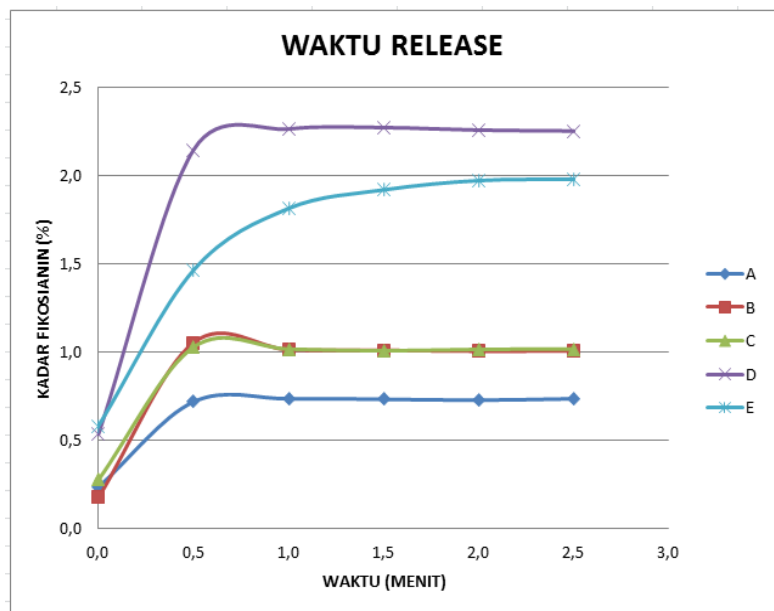

Gambar 2. Waktu Release Fikosianin

Berdasarkan waktu release fikosianin, dapat diketahui bahwa semakin tinggi konsentrasi karagenan sebagai bahan penyalut, maka semakin lama waktu release fikosianin. Waktu release berhubungan 
dengan pelepasan bahan inti dalam media cair. Mehrad et.al., (2015) menyatakan bahwa ikatan polimer yang bersifat hidrofilik pada bahan penyalut akan menyebabkan relaksasi yang menyebabkan bahan inti akan terlepas dari matriks.

Mikrokapsul fikosianin dengan konsentrasi karagenan $0 \%, 0,25 \%, 0,5 \%$, dan $0,75 \%$ memiliki waktu release berkisar antara $0,5-1,0$ menit. Waktu release fikosianin dengan konsentrasi karagenan $1 \%$ adalah lebih dari 3 menit. Hal ini terlihat dari kadar fikosianin yang masih menunjukkan peningkatan setelah waktu 3 menit. Semakin lamanya waktu release menunjukkan adanya interaksi maltodekstrin, karagenan, dan fikosianin yang semakin kuat. Semakin lama waktu release fikosianin juga menunjukkan bahwa sifat fisik mikrokapsul semakin stabil. Hal ini juga berhubungan dengan kelarutan karagenan yang rendah pada suhu kamar, sehingga mampu mengikat dengan kuat fikosianin dalam mikrokapsul. Karagenan sebagai bahan penyalut dapat melindungi dan mempertahankan fikosianin yang berada di dalam mikrokapsul. Mehrad et.al., (2015) yang mengenkapsulasi minyak ikan Menhaden dengan bahan penyalut yang berbeda, menyatakan bahwa minyak ikan Menhaden yang disalut dengan karagenan dan maltodekstrin dapat release sempurna dalam waktu tiga jam.

\section{KESIMPULAN}

Penggunaan bahan penyalut terbaik dalam mikroenkapsulasi fikosianin berdasarkan sifat fisiknya ditunjukkan pada Formula E, yaitu menghasilkan warna yang paling biru, zat padat terlarut yang rendah dan waktu release yang paling lama dibanding formula yang lain. Hal ini menunjukkan bahwa maltodekstrin dan karagenan merupakan perpaduan yang baik dalam proses mikroenkapsulasi fikosianin, dengan konsentrasi karagenan $1 \%$.

\section{UCAPAN TERIMA KASIH}

Penulis mengucapkan terimakasih kepada Universitas Diponegoro yang telah membiayai penelitian ini melalui dana PNBP pada tahun 2015.

\section{DAFTAR PUSTAKA}

Assosiation of Official Analytical Chemist. (2005). Official Methods of Analysis. AOAC. Washington, United States.

Belscak-Cvitanovic, A., Stojanovic, R., Manojlovic, V., Komes, D., Cindric, I.J., Nedovic, V., and Bugarski, B. (2011). Encapsulation of Polyphenolic Antioxidants from Medical Plant Extracts in Alginate-Chitosan System Enhanced with Ascorbic Acid by Electrostatic Extrusion. Food Research International, 44:1094-1101.

Bertolin, T.E., Farias, D., Guarienti, C., Petry, F.T.S., Colla, L.M., and Costa, J.A.V. (2011). Antioxidant Effect of Phycocyanin on Oxidative Stress Induced with Monosodium Glutamate in Rats. Brazilian Archives of Biology and Technology 54(4) : 733-738.

Chaiklahan, R., Chirasuwan, N., Loha, V., Tia, S., and Bunnag, B. (2011). Separation and purification of phycocyanin from Spirulina sp. using a membrane process. Bioresource Technology, 102:7159-7164.

Chaiklahan, R., Chirasuwan, N., and Bunnag, B. (2012). Stability of phycocyanin extracted from Spirulina sp. : influence of temperature, $\mathrm{pH}$ and preservatives. Process Biochemical, 47:659-664.

Dewi, E.N., Darmanto, Y.S., and Ambariyanto. (2012). Characterization and Quality of Semi Refined Carrageenan (SCR) Products from Different Coastal Waters Based on Fourier Transform Infrared Technique. Journal of Coastal Development 16(1) : 25-31.

Kamble, S.P., Gaikar, R.B., Padalia, R.B., and Shinde, K.D. (2013). Extraction and 
Purification of C-Phycocyanin from Dry Spirulina Powder and Evaluating It's Antioxidant, Anticoagulation and Prevention of DNA Damage Activity. Journal of Applied Pharmaceutical Science 3(8) : 149-153.

Kanpairo, K; Usawakesmanee, W; Sirivongpaisal, P; and Siripongvutikorn, S. (2012). The Compositions and Properties of Spray Dried Tuna Flavor Powder Produced from Tuna Precooking Juice. International Food Research Journal 19(3) : 893-899.

Mehrad, B., Shabanpour, B., Jafari, S.M., and Pourashouri, P. (2015). Characterization of Dried Fish Oil from Menhaden Encapsulated by Spray Drying. Aquaculture, Aquarium, Conservation \& Legislation International Journal of The Bioflux Society 8(1) : 57-69.

Purnomo, W., Khasanah, L.U., dan Anandito, R.B.K. (2014). Pengaruh Ratio Kombinasi Maltodekstrin, Karagenan, dan Whey Terhadap Karakteristik Mikrobahan penyalut Pewarna Alami Daun Jati (Tectona grandis L.f.). Jurnal Aplikasi Teknologi Pangan 3 (3) : 121129.

Rojas-Nery, E., Garcia-Martinez, I., and Totosaus, A. (2015). Effect of Emulsified Soy Oil with Different Carrageenans in Rennet-Coagulated Milk Gels. International Food Research Journal 22(2) : 606-612.

Sedjati, S., Yudiati, E., dan Suryono. (2012). Profil Pigmen Polar dan Non Polar Mikroalga Laut Spirulina sp. dan Potensinya Sebagai Pewarna Alami. Jurnal Ilmu Kelautan, 17 (3):176 - 181.

Seo, Y. C., Choi, W. S., Park, J. H., Park, J. O., Jung, K. H., and Lee, H. Y. (2013). Stable Isolation of Phycocyanin from Spirulina platensis Associated with High-Pressure Extraction Process. Int. J. Mol. Sci., 14:1778-1787.
Setijawati, D. (2014). Carrageenan from Euchema sp and Concentration Difference as Encapsulation Material Toward Lactobacillus acidophilus Viability at Simulation GI Tract $\mathrm{pH}$ Condition. J. Basic. Appl. Sci. Res 4(6) : 261-268.

Setijawati, D., Wijana, S., Aulaniam., dan Santosa, I. (2011). Viabilitas dan Struktur Mikrokapsul L. acidophilus dengan Bahan Penyalut Karaginan Semi Murni Jenis Eucheuma cottonii. Jurnal Teknologi Pangan 2(1) : 50-67.

Sivasankari, S., Naganandhini., and Ravindran, D. (2014). Comparison of Different Extraction Methods for Phycocyanin Extraction and Yield from Spirulina platensis. International Journal of Current Microbiology and Applied Sciences 3(8) : 904-909.

Srihari, E., Lingganingrum, F.S., Hervita, R., dan Wijaya S, H. (2010). Pengaruh Penambahan Maltodekstrin pada Pembuatan Santan Kelapa Bubuk. Seminar Rekayasa Kimia dan Proses. Jurusan Teknik Kimia Universitas Diponegoro. Hal 1-7.

Supriyadi dan Rujita, A.S. (2013). Karakteristik Mikrokapsul Minyak Atsiri Lengkuas dengan Maltodekstrin sebagai Enkapsulan. J. Teknol. dan Industri Pangan 24(2) : 201-208.

Supu, I., Akhiruddin., dan Setyaningsih, I. (2013). Studi Fluoresens Fikosianin dari Mikroalga Spirulina platensis dan Fotosensitisasi Nanopartikel $\mathrm{TiO}_{2}$ Anatase. Jurnal Biofisika 9(1) : 37-47.

Utami, D.A.S; Widanarni; and Suprayudi, M.A. (2015). Administration of Microencapsulated Probiotic at Different Doses to Control Streptococcosis in Tilapia (Oreochromis niloticus). Microbiology Indonesia 9(1) : 17-24.

Wariyah, C. (2014). Sifat Fisik Instan Lidah Buaya (Aloe vera var. chinensis) dan Rendemen Hasil Mikroenkapsulasi 
Menggunakan Spray Dryer. Prosiding SNKP. Hal. 111-116.

Wenno, M.R., Thenu, J.L., dan Lopulalan, C.G.C. (2012). Karakteristik Kappa Karaginan dari Kappaphycus alvarezii pada Berbagai Umur Panen. JPB Perikanan 7(1) : 61-67.

Yan, M., Liu, B., Jiao, X., and Qin, S. (2014). Preparation of phycocyanin microcapsules and it's properties. $J$.
Food and Bioproducts Processing, 92:89-97.

Yuniwati, M; Kusuma, A.W; dan Yunanto, F. (2012). Optimasi Kondisi Proses Ekstraksi Zat Pewarna dalam Daun Suji dengan Pelarut Etanol. Prosiding Seminar Nasional Aplikasi Sains \& Teknologi (SNAST) Periode III. Hal 257-263. 